\title{
Mímesis a contrapelo: ficção e autobiografia nos romances Berkeley em Bellagio e Lorde, de João Gilberto Noll Marcio Renato Pinheiro da Silva
}

Desde o princípio dos anos oitenta, um dos traços mais característicos à obra do romancista e contista João Gilberto Noll tem sido sua constante experimentação com a escrita, oscilando desde uma eloquência neobarroca até o despojamento retórico cuja concisão chega a como que esvariar o conflito dramático. ${ }^{1}$ A estas variações, entretanto, contrapõe-se o recorrente perfil de suas personagens (em especial, de suas protagonistas), cujas trajetórias contingentes, em tempos e em espaços que se sobrepõem e se interpenetram com frequência, inviabilizam qualquer forma de redenção ou de aprendizado. Daí, uma certa opacidade da experiência, o que acaba incidindo sobre a própria identidade das personagens, tornando-as permeáveis umas às outras e inviabilizando, em muitos casos, a articulação de um nome próprio:

\footnotetext{
"Submersos em acontecimentos cuja significação se esgota em sua mera faticidade, entendendo o tempo vazia e homogeneamente, viajando por terras que já não oferecem outridades a partir das quais afirmar a identidade, os personagens de Noll se enfrentam ao bloqueio da experiência e do nome próprio" (AVELAR, 2003, p. 228).
}

Daí, também, a inexistência de maiores dimensões psicológicas:

\begin{abstract}
"não há uma interioridade [...]: tudo é efeito de uma linguagem que reproduz mimeticamente o movimento de deslocamento, de fuga, que está no centro dos diferentes enredos. [...] seja qual for o livro, o protagonista é invariavelmente um ser errante [...] que, ao buscar o exílio, encontra cárceres renovados" (PINTO, 2005, p. 118-119).
\end{abstract}

Tempos e espaços indefinidos, sobrepostos; opacidade da experiência; permeabilidade identitária; não-articulação de um nome próprio nem de maiores dimensões psicológicas; reincidente alternância entre errância e cárcere - esses traços, firmados e seguidos ao longo de cerca de vinte anos, sofrem certa modificação em dois de seus últimos romances, Berkeley em Bellagio, de 2002, e Lorde, de 2004. Nestes, as personagens (especificamente, os narradores) são escritores brasileiros de meia-idade cujas respectivas estadas no exterior suscitam algo, até então, inédito à obra de Noll: a identificação entre autor empírico e personagem-narrador, entre o narrado e o supostamente vivido. Como sintetiza Diana Irene Klinger:

O narrador de Berkeley em Bellagio se chama João, é um escritor de meia-idade, brasileiro, professor da Universidade de Berkeley na Califórnia - como o foi Noll -, que recebe - como recebeu Noll - um convite de uma fundação norte-americana para passar uma temporada e escrever um romance numa residência de escritores em Bellagio, na Itália. ${ }^{2}$ Da mesma forma, Lorde foi composto durante uma temporada que o autor gaúcho passou em Londres como escritor residente do King's College. O protagonista também é um escritor brasileiro que escreveu sete livros e que vai à Inglaterra a convite de uma instituição britânica (KLINGER, 2007, p. 58-59). 
Daí que Berkeley em Bellagio e Lorde possam ser tomados como relatos de teor autobiográfico, relativos às experiências de Noll no exterior - isto, frise-se, em concomitância à sua veiculação como ficção. Delineia-se, portanto, uma hesitação entre autobiografia e ficção, problematizando as possibilidades de enquadramento desses romances em meio às práticas discursivas correntes e desestabilizando, com efeito, os parâmetros elementares à sua leitura e à sua interpretação.

Frente a isso, costuma-se atribuir, a Berkeley em Bellagio e a Lorde, uma espécie de fusão entre escrita e experiência, entre arte e vida. Conforme, por exemplo, Flávio Carneiro:

\footnotetext{
"Ao se mudar para dentro de seu próprio livro, o autor [joão Gilberto Noll] reitera um dos traços marcantes de sua prosa: a relativização de limites. [...] o narrador atravessa também as raias que delimitam vida e obra, não para firmar no papel uma autobiografia autorizada mas antes para desautorizar qualquer distinção exata entre o vivido e o escrito" (2005, p. 106, colchetes meus).
}

Essa indistinção, aliás, tem sido considerada típica à literatura brasileira atual, sobretudo, quando assimilada a questões recorrentes à contemporaneidade, tais como a ruptura com concepções de arte e de literatura que, supostamente, primam por sua sacralização e por sua estratificação institucional, a impossibilidade ou a impertinência da distinção entre realidade sócio-empírica e cultura e entre esta e as commodities etc. (cf. KLINGER, 2007; MORICONI, 2006; VIEGAS, 2007).

De fato, em relação a Berkeley em Bellagio e a Lorde, este artigo sustenta hipóteses opostas às apresentadas acima. Primeiramente, acredita-se que, nos romances de Noll, a relação entre autobiografia e ficção seja bem mais complexa do que a mera promoção de uma indistinção. Isto porque (algo flagrante mesmo em uma primeira e elementar leitura) determinados procedimentos retórico-discursivos problematizam ou mesmo inviabilizam qualquer identificação entre o narrado e o supostamente vivido. Aí, tanto quanto (ou mais do que) indistinção, delineiam-se diferenças e, até, incompatibilidades entre autobiografia e ficção. De modo que a relação desses pólos entre si nos romances de Noll, bem como suas implicações no âmbito das relações entre literatura e sociedade, permanecem inexploradas. E é a isto, precisamente, que este artigo pretende dedicar-se.

Para tanto, a interpretação dos romances será centrada na especulação sobre as semelhanças e, principalmente, sobre as diferenças entre autobiografia e ficção. Diferenças, estas, que remetem não a distintas naturezas, mas, apenas, a diferentes graus. E graus de uma mesma escala, relativa às modulações ideológicas inerentes à articulação desses termos entre si no bojo da própria narração. Daí que, neste artigo, não entra em pauta qualquer especulação de teor substancialista sobre o que vem a ser autobiografia, nem sobre o que vem a ser ficção, nem a respeito das dicotomias subjacentes à articulação da polaridade entre esses termos ("verdadeiro" versus "falso", "realidade" versus "imaginação" etc.). Tampouco se reduzem essas questões a um mero efeito de linguagem, o que, a propósito, "equivale simplesmente a inverter o determinismo cientificista o século XIX" (COSTA LIMA, 2000, p. 246). Interessam, aqui, os sentidos da tensão entre autobiografia e ficção no âmbito da mímesis, pressupondo, aí, a atuação dessas instâncias como valores intrinsecamente atuantes, além de ideologicamente demarcáveis, tanto nos próprios romances quanto nos mais variados estratos da vida social. ${ }^{3}$ 


\section{Confortável exílio branco}

Conforme já dito, Berkeley em Bellagio, lançado em 2002, remonta, inicialmente, ao período em que Noll fora professor de Cultura Brasileira junto à Universidade da Califórnia (UCLA), campus de Berkeley, no final da década de noventa. Aliás, logo no princípio do primeiro e único parágrafo do romance, já se indiciam tais circunstâncias:

Ele não falava inglês. Quando deu seu primeiro passeio pelo campus de Berkeley, viu não estar
motivado. Saberia voltar atrás? Não se arrependeria ao ter de mendigar de novo em seu país
de origem? Fingir que não pedia pedindo refeições, ou a casa de veraneio de um amigo em
pleno inverno para escrever um novo livro - ah, quando os pinguins chegam à costa daquele
extremo sul do Brasil, o vento passa destelhando e uma voz noturna chama, chama pelo
desaparecido infante... Ele não falava inglês e se perguntava se algum dia arranjaria mais
disposição para aprender mais uma língua além de seu português viciado, com cujas palavras
já não conseguia dizer metade do que alcançava tempos atrás (NOLL, 2003, p. 09). ${ }^{4}$

Trata-se, bem se vê, de um escritor brasileiro que não domina a língua materna do país em que se encontra. Como, no Brasil, sua sobrevivência material por meio do trabalho com literatura é pouco viável, aceita a oportunidade de trabalho afim no exterior. Mas essa oportunidade pouco o motiva, uma vez que concebe seu papel como sendo o de "um emissário de pérolas brasileiras que os alunos americanos pareciam receber com a efusão conveniente às melhores notas - para depois de formados poderem operar as mais produtivas relações internacionais para o país deles controlar melhor o cosmos" (NOLL, 2003, p. 14). Tanto que chega a conceber que melhor seria retornar ao Brasil. Mas, ao mesmo tempo, "perguntava a si mesmo se voltando a seu país teria teto, emprego, as famigeradas refeições" (NOLL, 2003, p. 19). Por isso, o fato de não dominar a língua inglesa converte-se em um problema. Afinal, dada a dificuldade de sobrevivência no Brasil, “(...) precisava mesmo era ir à ação, falar inglês, testemunhar nessa língua a todos que pudessem se interessar por sua vida. Quase ninguém naquela terra, era verdade, não podia negar - mas com o passado dos verbos irregulares e expressões idiomáticas nos lábios, teria mais chances de protagonizar histórias, optar por viver definitivamente naquele país com um bom salário de professor de cultura brasileira” (NOLL, 2003, p. 11-12).

Este impasse pouco permanece, pois não tarda o convite de uma fundação norte-americana para que siga até Bellagio, na Itália. Aí, passa-se a maior parte do romance, mais precisamente, em uma espécie de hotel da própria fundação, que abriga artistas e, sobretudo, acadêmicos norte-americanos. A proposta da fundação é promover o convívio entre diferentes estratos da intelligentsia norte-americana e, em menor grau, de outros países, tendo em vista uma espécie de circulação do saber. No caso específico do escritor brasileiro, cabe-lhe a escrita de um livro, o qual ele mal esboça durante sua estada de cerca de seis anos no exterior.

Em Bellagio, "exílio branco no conforto de universidades e fundações americanas" (NOLL, 2003, p. 43), a personagem mostra-se arredia à convivência com os acadêmicos norte-americanos e demais artistas, seja, inicialmente, por não dominar o idioma, seja pelos poucos interesses em comum. Os raros encontros com os colegas de estada são 
marcados, sempre, pelo enfado e pela ironia: "[...] fui para perto de um grupo que ouvia atentamente a fala da poeta tcheca toda liquefeita em vinho a relatar sua amizade estreita com João Paulo II; ganhou algum prêmio do Vaticano, algo assim, talvez uma medalha católica dedicada aos poetas, tudo eu ouvia como sempre ouvia os cortesãos da Fundação, pegando pedaços, nacos de frases, logo me desinteressando" (NOLL, 2003, p. 38). Fogem, entretanto, a este padrão um engenheiro equatoriano, funcionário de uma grande instituição filantrópica e debutante na política, que "falava português perfeitamente", e um dramaturgo e professor de Chicago. Ambos incitam o escritor brasileiro a rever seu projeto literário, ressaltando o desajuste, o alheamento e a ingenuidade de sua literatura frente ao contexto sócio-econômico globalizado e às demandas mercadológico-culturais aptas à circulação (massiva) nesse mesmo contexto.

Apesar de sua inércia e de sua reclusão, "Esse ninguém que acabei sendo em meio à Fundação americana” (NOLL, 2003, p. 52) quer permanecer por ali, dada a dificuldade de sobrevivência por meio do trabalho com literatura no Brasil. Tanto que, em vários momentos, desespera-se ao pensar que pode não mais ser benquisto pela fundação: "Vou direto para o meu quarto, antes procuro investigar se a porta ainda mostra o meu nome - está ali, suado pra chegar até esse dia nessa pompa, tendo como moldura uma fina linha dourada cheia de voltinhas, de meandros, ah, entro aliviado no meu quarto, vejo que ele ainda é meu" (NOLL, 2003, p. 70). E esse desejo de permanência atua como elemento repressor de qualquer lembrança ou ato, em tese, ideologicamente contrário à fundação ou, em âmbito mais geral, à política econômica norte-americana:

Tirei algo do bolso, abri o papel amarelado: era uma foto que custei a identificar... ali estava eu
na tarde ensolarada, camisa aberta ao peito, em primeiro plano numa passeata contra a Alca no
verão porto-alegrense, claro, durante o Fórum Social Mundial; eu segurando um cartaz que
dizia "Não à Alca" - quem tinha tirado aquela foto, por que agora dentro de meu bolso? Só
tinha uma coisa a fazer com ela: apertá-la, apertá-la o suficiente até torná-la uma coisinha
ínfima. Assim fiz. E enfiei-a sem dor pelo cu (NOLL, 2003, p. 57).

De qualquer modo, retorna ao Brasil. Não por conta de alguma acusação de subversão, como tanto o temia, mas, simplesmente, por que a temporada de hospedagem em Bellagio acaba para todos. O escritor brasileiro, inclusive, é o último a deixar o hotel da instituição norte-americana.

Em meio a seu retorno, após o check-in no aeroporto de Malpensa, em Milão, depara-se com uma leva de refugiados afegãos, que se dirigem, também, a Porto Alegre (a título de curiosidade: de fato, em 2001, conforme o Afeganistão é invadido em represália à queda das Torres Gêmeas, cinco famílias afegãs refugiam-se em Porto Alegre). Afeiçoa-se a uma criança afegã, com a qual tenta estabelecer contato por meio de brincadeiras e de caretas. Mas "ela nem ao menos me olha como todas as crianças que pegam a te olhar quando começas na rua ou no ônibus com micagens" (NOLL, p. 81). De volta a Porto Alegre, já readaptado ao Brasil, o escritor brasileiro reata com um ex-amante, Léo, passando a viver com este e sua pequena filha, Sarita. Por fim, encerra-se o romance com o escritor brasileiro levando Sarita ao acampamento em que se encontram os refugiados afegãos, para que conheça a menina que lhe chamara a atenção quando de seu retorno ao Brasil. 
Feita esta breve descrição do romance, vejamos as tensões entre autobiografia e ficção. Para isso, são necessárias algumas observações prévias sobre as semelhanças e diferenças entre autobiografia e ficção, de modo que, em seguida, sejam contrapostas a Berkeley em Bellagio.

Philippe Lejeune, certamente o mais difundido estudioso da chamada literatura íntima (diário, autobiografia, auto-retrato, blog etc.), considera impraticável a distinção entre autobiografia e ficção tomando um relato, apenas, por si mesmo. Isto, porque não existem características retórico-estilísticas específicas a um texto autobiográfico. O que diferencia uma narrativa ficcional de uma autobiográfica são as convenções adotadas em seu processo de leitura, a maneira como o leitor lida com aquilo que lê. É, também, o que afirma Paul De Man, para quem a autobiografia "não é um gênero ou um modo, mas uma figura de leitura ou de entendimento” (DE MAN, 1979, p. 921, tradução minha). ${ }^{5}$ Por isso, Lejeune julga ser fundamental a existência de um pacto autobiográfico entre autor (via texto) e leitor; pacto, este, segundo o qual o leitor deve identificar o sujeito do discurso ao autor empírico. Essa identificação deve ser incondicional, sem deixar qualquer espaço para ambiguidade, para qualquer gradação que não a univocidade: "a autobiografia não comporta graus: é tudo ou nada” (LEJEUNE, 2008, p. 25). A mínima fissura nesse pacto mina sua validade, resvalando em provável ficção.

É viável o estabelecimento de um pacto autobiográfico na leitura de Berkeley em Bellagio? A estada de João Gilberto Noll na Califórnia e em Bellagio, bem como seu retorno a Porto Alegre e o deslocamento de refugiados médio-orientais ao sul do Brasil - todos estes eventos acontecem, também, fora do âmbito da ficção. De modo que, por meio deles, seria viável, sim, a instauração de um pacto autobiográfico. Mas, de fato, na tessitura mesma do relato, essa possibilidade não é sequer minimamente esboçada. Não há qualquer instância discursiva que solicite um vínculo com o autor empírico, nem se requer veridicidade àquilo que se narra - operações, estas, características à composição de um pacto autobiográfico.

Ao mesmo tempo, retomando Paul De Man, seria possível que um leitor tomasse, caso o quisesse, a autobiografia como sendo a principal "figura de leitura ou de entendimento" de Berkeley em Bellagio? Trata-se de uma alternativa bastante discutível. Não por conta da veridicidade ou não dos pormenores narrados, mesmo porque a maior parte destes é de caráter imaginário, relativos que são à vida interior do escritor brasileiro. A questão é bem mais sutil, sendo perceptível na sinuosidade retórica inerente ao próprio relato.

Senão, atentemos aos seguintes excertos:

Ele não falava inglês e se perguntava se algum dia arranjaria mais disposição para aprender mais uma língua além de seu português viciado, com cujas palavras já não conseguia dizer metade do que alcançava tempos atrás (NOLL, 2003, p. 09).

[...] ele pergunta sobre o que que eu escrevo, vou lá filosofando em torno do meu personagem de sempre que aparece a cada livro; ele pergunta meio irritado o que acontece de fato nos meus livros, digo que não sei contar talvez porque nada aconteça de fato nessas minhas histórias, mas conte, conte o que de fato acontece nesse não-acontecer - nada, para!, respondo no meu inglês irretocável (NOLL, 2003, p. 59). 


\begin{abstract}
Mostra o passaporte, passa pelo detector de metais ou até quem sabe o de mentiras, olha mais uma vez no painel eletrônico a confirmação da hora do seu vôo, tudo ok, em cima, agora é só sentar em torno de hordas de árabes ou assemelhados com suas mulheres silenciosas, algumas de lenço na cabeça - eles cheiram à fuga, hindus agora chegam, são todos fugitivos?, penso eu, o que aconteceu no mundo nesse tempo em que vivi na Fundação americana sem TV disponível [...]? (NOLL, 2003, p. 79-80, grifo do autor).
\end{abstract}

O primeiro excerto consiste em algumas das sentenças iniciais do romance; o segundo relata parte da conversa entre o escritor brasileiro e o dramaturgo e professor norte-americano; o terceiro, o check-in no aeroporto de Malpensa, em Milão. Nota-se, no primeiro excerto, que a narração dá-se em terceira pessoa; no segundo excerto, em primeira pessoa; no terceiro excerto, começa-se em terceira pessoa e, no decorrer de um mesmo período, passa-se à primeira. Por que, aí, a variação da instância narrativa entre a primeira e a terceira pessoas do discurso?

Essa variação não é aleatória. De fato, predomina a narração em primeira pessoa. As ocorrências da terceira pessoa são vinculadas ao deslocamento espacial-geográfico da personagem principal e à sua subsequente introdução a novos espaços. Tanto que, quando nestes, a própria personagem assume a narração (primeira pessoa). Conclui-se, portanto, que o deslocamento espacial suscita uma espécie de estranhamento ou de distanciamento da personagem consigo mesma (terceira pessoa), de perda temporária dos referenciais a partir dos quais ela se define tanto para si mesma quanto em relação ao (e para o) outro. Quando já totalmente imersa em novo ambiente, apaziguam-se eventuais conflitos tanto consigo mesma quanto entre si e o ambiente, retornando, portanto, à narração em primeira pessoa.

E isto é bastante esclarecedor: essa hesitação identitária acontece, precisamente, em meio à narração de eventos que encontram veridicidade incontestável para além da ficção (o princípio na Califórnia; a ida a Bellagio; a saída de Bellagio e a volta a Porto Alegre). Portanto, quando o relato remete, em linhas gerais, ao supostamente (ou ao possivelmente) vivido, a instância narrativa e a personagem principal dissociam-se, estranham-se (narração em terceira pessoa). Já quando a personagem assume, ela mesma, a narração (identificação), o relato centra-se em pormenores relativos, sobretudo, à vida interior do escritor brasileiro. E seria bastante delicado (para não dizer impertinente) sancionar tais pormenores quanto à sua veridicidade ou à sua verificabilidade empíricas: afinal, eles são relativos, sobretudo, à imaginação. Em suma, quando é possível identificar o factual à narração, quando se trata de algo potencialmente autobiográfico, instância narrativa e personagem estranham-se, distanciam-se; quando a narração remete, sobretudo, a si mesma, projetando um âmbito eminentemente ficcional, instância narrativa e personagem identificam-se.

Há, ainda, outro fator a ser somado a esse jogo de forças entre autobiografiadistanciamento-estranhamento e ficção-identificação. Retomemos os dois primeiros excertos de Berkeley em Bellagio dentre os três que acabamos de discutir. Nota-se, no primeiro, relativo ao princípio do romance, que "Ele não falava inglês" (NOLL, 2003, p. 09). Já no segundo, ao dialogar com o dramaturgo e professor norte-americano, o escritor brasileiro afirma: "respondo no meu inglês irretocável" (NOLL, 2003, p. 59). Pode-se imaginar que, em princípio, o escritor brasileiro não falava inglês e que, 
com o tempo, adquiriu fluência nessa língua; essa aquisição seria motivada, inclusive, pela necessidade de sobrevivência material. Mas não é isso o que acontece. A fluência em inglês dá-se de maneira abrupta, de uma forma que o próprio narrador reconhece como sendo pouco crível: "It's ok, it's ok, me surpreendi parlando desse jeito num repente. [...] era que eu já pensava em inglês, já não conseguia processar um pensamento que não fosse em inglês, se perguntassem de onde tinha vindo a repentina fluência nessa língua, um cínico que me ouvia cá dentro responderia que eu fora iluminado durante o meu longo, longo sono pelo Espírito Santo - Holy Ghost, é lógico, tudo em inglês" (NOLL, 2003, p. 56, grifos do autor). E ocorre o mesmo quando retorna ao Brasil. Em princípio, não tem a menor fluência em língua portuguesa: "A primeira coisa que fiz no aeroporto de Porto Alegre foi deixar a bagagem num guarda-volumes e me dirigir ao balcão de informações e perguntar onde podia encontrar na cidade algum curso de português para estrangeiros" (NOLL, 2003, p. 85). Até que, subitamente, começa a falá-la, em detrimento do inglês. De modo que o distanciamento entre instância narrativa e personagem desdobra-se em uma fissura não só identitária, mas, também, linguístico-idiomática. Logo, instância narrativa e personagem, a personagem consigo mesma, o idioma da personagem e o falado no ambiente que a circunda - tudo se dissocia nas passagens potencialmente autobiográficas. Por outro lado, tudo se associa em clave ficcional.

Uma última questão relativa às eventuais identificações entre o narrado e o supostamente vivido: seria possível dizer que o romance devido à fundação norte-americana e o próprio Berkeley em Bellagio são um mesmo e único relato? ou, ainda, em lógica mais proustiana, Berkeley em Bellagio seria uma espécie de primeira versão de um romance ainda por vir? Fato é que o escritor brasileiro escreve muito pouco, praticamente nada. Da raríssima vez em que diz fazê-lo, consta o seguinte:

[...] é só sentar à frente do meu laptop e pronto, lá vem a história que eu não conhecia ainda, é isso, a história que eles querem que eu faça: conte uma história, não complique; alguma coisa que dê para amanhã mostrar pros nossos filhos, netos quem sabe; o certo é que já estarão bem longe das letras, e então pra fixar-lhes a atenção é necessário contar direito o que se passou, sem a sombra do caos de onde viemos, pois no ambiente uterino tudo é caos, e não é de regressão que eles precisam, é de muito mais, de um mundo que desdiga o nosso (NOLL, 2003, p. 70, grifo do autor).

Como visto ao longo deste artigo, Berkeley em Bellagio é um relato que se vale de dados potencialmente autobiográficos para, ao cabo, tender à ficção; relato que, composto por um único parágrafo, alterna sua narração entre a primeira e a terceira pessoas do discurso, havendo pouquíssima ação senão os embates interiores de um escritor brasileiro que ora pretende estabelecer-se no exterior para melhor manter-se materialmente e ora pretende retornar ao Brasil, que ora é fluente em inglês e ora em português - todas essas características não "desdizem o caos de nosso mundo", como "eles querem"; não se trata de algo "direto" e "sem complicações". Berkeley em Bellagio é bem o contrário disso tudo. 
Flagrante, aí, uma disjunção retórico-performativa entre, de um lado, aquilo que o escritor brasileiro pensa fazer ou escrever e, de outro, aquilo que a narração, de fato, faz. E isto não deixa de repetir-se em se tratando das fissuras típicas a Berkeley em Bellagio (entre autor empírico e narrador, entre narrador e personagem, da personagem consigo mesma etc.), articulando uma espécie de resistência à autobiografia. Afinal, seja como pacto, seja como figura de leitura, a autobiografia implica a incompatibilidade de diversos elementos da narração entre si, dispersando-os, interditando sua reconciliação em torno de uma interpretação que permita assimilar o vivido ao narrado sem que as nuances deste sejam sacrificadas em prol da legitimação ideológica daquele. Problemas, estes, absolutamente inexistentes em uma leitura que tome Berkeley em Bellagio como sendo ficção.

Isso significa que quaisquer questões relativas à autobiografia devam ser descartadas no processo de leitura e de interpretação de Berkeley em Bellagio? Antes de especulações afins, vejamos o que Lorde pode acrescentar a esta discussão.

\title{
2. "Je est un autre"
}

\begin{abstract}
Parece fácil dizer “então eu vim”- alguém todo preparado para atravessar o Atlântico de uma hora para outra, sem ter nada o que deixar que carecesse de sua presença. Mas afirmo que essa é uma das frases mais espinhosas que já pronunciei nesta já não tão curta existência: "Então eu vim". Poderia dizer que antes eu teria de resolver isso e aquilo. Não, que nada, eu teria apenas de trocar minha solidão de Porto Alegre pela de Londres. E ter na Inglaterra uma graninha extra para me sustentar (NOLL, 2004, p. 10, aspas do autor).
\end{abstract}

Eis algumas das sentenças do primeiro parágrafo de Lorde. Da mesma maneira que em Berkeley em Bellagio, a narrativa remete, em princípio, à identificação entre o relatado e o vivido. Nesse caso, precisamente, trata-se do período em que Noll estivera em Londres, atuando como escritor residente do King's College (instituto vinculado à University of London). Ao contrário de Berkeley em Bellagio, não há qualquer alteração na voz assumida pela instância narrativa em Lorde: do começo ao fim, o romance é narrado em primeira pessoa, havendo total identificação entre tal instância e a personagem principal.

Esta, novamente, é "um brasileiro que, vá lá, escrevia seus livros muitas vezes bem recebidos pela crítica quando não pelo público” (NOLL, 2004, p. 20). Também, novamente, trata-se de um escritor que enfrenta dificuldades para sobreviver materialmente no Brasil, o que o motiva a aceitar um convite de uma instituição inglesa para uma estada em Londres. Mas, diferentemente de Berkeley em Bellagio, o escritor brasileiro em Lorde só sabe que uma instituição inglesa banca sua estada no exterior, e que isto tem a ver com o fato de ele ser escritor. Que instituição é esta, o que ela pretende com a presença dele ali, que tipo de atividade cabe a ele - nada disso é esclarecido ao longo de todo o romance, o que perturba, e muito, o escritor-narrador. Por outro lado, ele considera que "não haveria outro lugar para estar senão ali. Ou, pelo menos, não haveria uma escolha melhor. Estaria fazendo o quê no Brasil?” (NOLL, 2004, p. 21). A incômoda incerteza quanto àquilo que deve ser feito, somada ao desejo de ali se fixar, são as forças que desencadeiam o que se pode chamar de as três degradantes metamorfoses da personagem ao longo do romance. 
A primeira delas diz respeito à tentativa de permanência em Londres por meio de um comportamento, por assim dizer, modelar, projetado a partir daquilo que a instituição britânica supostamente requer. Aí, o escritor brasileiro explicita sua submissão e sua subserviência em meio a eventos que beiram o grotesco. Exemplo disso é o fato de não oferecer resistência a uma tentativa de aliciamento por parte de um professor britânico, bem como o de sujeitar-se a enigmáticos exames de saúde por solicitação da instituição, os quais lhe causam uma espécie de amnésia e, com efeito, de crise identitária. Isto, quando o narrador não é o agente de sua própria reificação. ${ }^{6}$ Mas nada surte efeito no que se refere ao esclarecimento das razões para estar ali: “(...) cheguei à nítida conclusão de que a vida não me queria em perfeitas condições, é isso. Deu-me sete livros, é verdade. Mas, apesar deles, onde eu encontrava a minha autonomia? Até quando escravo de uma maquinação secreta sem vislumbre de alforria? Já falei, ser escravo não é nada, mas que se saiba realmente de quem ou de quê" (NOLL, 2004, p. 68).

Como não descobre "de quem nem de quê", o escritor brasileiro abandona o comportamento modelar e passa à marginalidade: perambula a esmo, dorme nas ruas, presencia crimes etc. Mais ainda, quando o único representante da instituição inglesa com o qual travara contato suicida-se. Isto leva o escritor a bater carteiras, de modo a angariar fundos para permanecer incógnito na Inglaterra, não mais na dependência da “"bolsa' que o inglesinho me pagava” (NOLL, 2004, p. 82, aspas do autor). Consegue uma boa quantia, o que permite sua fuga para Liverpool.

Lá chegando, hospeda-se em um famoso hotel, onde é reconhecido por uma professora portuguesa, que, em nome da Universidade da Cidade de Liverpool, requer seus serviços: "estavam precisando com urgência de um professor de língua portuguesa - não de literatura, ela sublinhou, de um professor de português para o semestre seguinte. E quando me viu entrando no hotel se perguntou: quem mais indicado para ser um mestre em português do que um escritor da língua com todos esses livros no currículo?" (NOLL, 2004, p. 102-103). O narrador, obviamente, aceita o encargo: poderia, finalmente, permanecer na Inglaterra, legalmente e com meios financeiros para tanto.

Por fim, o escritor segue a um pub. Lá, conhece George, um estivador inglês, e o leva para o hotel. Passam a noite juntos. Na manhã seguinte, ao acordar, percebe que George já se fora. Nota algo estranho, como se não mais (se) reconhecesse (em) seu próprio corpo. Então, "O espelho confirmava, não adiantava adiar as coisas com indagações. Tudo já fora respondido. Eu não era quem eu pensava. Em consequência, George não tinha fugido, estava aqui. Pois é, no espelho apenas um: ele" (NOLL, 2004, p. 109). Reiterando: em uma espécie de Deus ex machina relativo à identidade, o anônimo escritor brasileiro metamorfoseia-se em George, um estivador inglês.

Passemos, agora, às questões relativas à tensão entre autobiografia e ficção.

De um lado, João Gilberto Noll é convidado pelo King's College a passar uma temporada em Londres; de outro, em Lorde, uma instituição incógnita convida um escritor brasileiro a passar uma temporada em Londres - afora essa semelhança, não há, praticamente, nenhum evento narrado em Lorde cuja ocorrência fora do âmbito da ficção possa ser comprovada. Mesmo porque a recorrência a eventos inconcebíveis ${ }^{7}$ exclui, compulsoriamente, qualquer especulação afim à veridicidade do narrado. Somando isso à inexistência de uma instância discursiva que solicite vínculo com o autor empírico, vê-se o quão inviável seria 
a instauração de um pacto autobiográfico em Lorde. E, se o leitor, por conta própria, recorresse à autobiografia como "figura de leitura ou de entendimento" do romance, tratar-se-ia de uma alternativa fadada, de antemão, à absoluta impropriedade. Afinal, o que dizer de uma eventual metamorfose de João Gilberto Noll em um estivador inglês?! ou do fato de o King's College não conceder maior suporte a Noll, levando-o a dormir nas ruas e a bater carteiras?

Vimos que uma leitura de Berkeley em Bellagio em clave autobiográfica é interdita por algumas disjunções retórico-discursivas, configurando uma espécie de resistência à autobiografia. Em Lorde, essa resistência torna-se como que intransponível: tamanha é a desproporção na tensão entre autobiografia e ficção que sua leitura em viés ficcional é menos uma possibilidade e mais uma precondição à sua própria legibilidade. Logo, facilmente se conclui que, entre autobiografia e ficção, a alternativa mais adequada tanto para Berkeley em Bellagio quanto (ou principalmente) para Lorde é a representada pela ficção.

Mas uma leitura que se ativesse aos romances em termos puramente ficcionais, ainda que coerente consigo mesma, ainda que adequada a critérios lógico-ideológicos por meio dos quais as práticas discursivas são sancionadas e, com efeito, instrumentalizadas em meio a diversos estratos da vida social - uma leitura de Berkeley em Bellagio e de Lorde em clave exclusivamente ficcional deixaria, sempre, um rastro de incompletude, de tensão não-resolvida, de dúvida a respeito de sua própria legitimidade. Afinal, ela operaria não a resolução da tensão entre ficção e autobiografia, mas, simplesmente, a exclusão sumária do pólo autobiográfico; exclusão, aliás, passível de reversão a cada (re)leitura. Daí que, por mais que tomar Berkeley em Bellagio e Lorde como ficção seja tanto possível quanto recomendável, isto não implica a exclusão sumária da autobiografia. Tampouco a admissão desta deve ser compreendida como sua domesticação, como sua circunscrição à inação. Afinal, ainda que residual, ainda que dificilmente coadunável à própria lógica subjacente às narrativas, é possível que a autobiografia desempenhe, sim, algum papel na mímesis eminentemente ficcional de Berkeley em Bellagio e de Lorde; papel, este, para além de um pacto autobiográfico ou de uma figura de leitura ou de entendimento.

Tentemos, pois, uma reflexão afim.

\section{3. "Monkey see, monkey do"}

Como fazê-lo, entretanto? Um primeiro passo nesse sentido consiste na tentativa de repensar o impasse acima esboçado (a exclusão do pólo autobiográfico de modo a viabilizar uma leitura em clave ficcional). Sendo assim, por que, até o momento, autobiografia e ficção foram tacitamente consideradas opostas e pouco conciliáveis entre si? por que a relação entre esses termos tende a traduzir-se em dicotomia ou em paradoxo? Provavelmente porque, quando contraposta à ficção, a autobiografia projeta a inscrição da subjetividade em âmbito factual, isto é, relativo à experiência empírico-perceptual. O que é esclarecedor, à medida que, a partir do ocaso das concepções substancialistas de mundo e em concomitância à articulação do sujeito secularizado na modernidade, o factual tem desempenhado a seguinte função: "Contra as 
presunções da razãa e as quimeras da imaginação, apresenta-se o fato. Enquanto indice do que é passivel de conbecimento, só o fato é compativel com um mundo que tem o sujeito individual por centro. [...] A devoção ao fato se impõe ao indivíduo enquanto indício de uma Lei, i.e., testemunho de um princípio homogeneizador" (COSTA LIMA, 2005, p. 70, grifos do autor). Ou, ainda, "a tematização da subjetividade provoca a abertura de uma diferenciação discursiva que a Idade Média desconhecera. A História e o fictício se separam. Aquela é exaltada, ao passo que este se confunde com o falso e o mentiroso. [...] a constituição da razão no Ocidente, desde a baixa Idade Média, trouxe consigo a repulsa do ficcional, fosse em nome da verdade histórica, fosse da moral cristã" (COSTA LIMA, 2007, p. 243 e 251). Daí que, quando contraposta à ficção, a autobiografia atua como um mecanismo de homogeneização e de coibição da imaginação via fato (e/ou via razão), bem como da própria ficção.

Frente a essas observações, como repensar a tensão entre autobiografia e ficção em Berkeley em Bellagio e em Lorde? Exclui-se, de antemão, considerá-los romances à clé, cujas remissões a pessoas e a eventos supostamente reais seriam uma espécie de cifra a ser desvendada. Basta lembrarmos que uma leitura que tome os romances como sendo inteiramente ficção é viável, ao passo que o contrário (como sendo inteiramente autobiografia) é inexequível - tudo isso indicia o caráter controverso de uma tal altemativa. Ademais, mesmo se praticável, uma leitura afim consistiria na submissão da ficção ao fato, em sua domesticação e homogeneização, circunscrevendo-a aos estritos limites do supostamente verídico.

Já o contrário disso parece bem mais condizente com Berkeley em Bellagio e com Lorde. Ou seja, pode-se pressupor que os romances valem-se de alguns dados potencialmente verídicos para, então, ficcionalizá-los, quebrando o pacto de autobiográfico inicialmente sugerido. ${ }^{8} \mathrm{E}$ essa ficcionalização leva à suspensão de questões relativas à veracidade ou não dos relatos - incluindo, aí, os dados potencialmente autobiográficos de que se apropriam os romances. Logo, a mímesis articulada em Berkeley em Bellagio e em Lorde toma o potencialmente verídico e adia as sanções correntes a seu respeito, adiando, igualmente, seus valores e funções.

Eis uma operação que pode abranger desde a transformação do socialmente já dado em objeto de reflexão até o apaziguamento do impulso questionador da ficção, nivelando-a ideologicamente àquilo considerado verídico. Dizendo de outro modo, essa mímesis, de um lado, pode instaurar um distanciamento crítico em relação àquilo que se considera fato, às suas funções quando contraposto à ficção (a homogeneização e a coerção da imaginação), bem como em relação aos suportes ideológicos envolvidos nesse processo. Também, de outro lado, essa mesma mímesis pode valer-se do factual e submetê-lo à ficção para, ao cabo, igualar ambos, consistindo, justamente, em um mecanismo de homogeneização e de coerção ideológicas da imaginação e da ficção. Obviamente que essas duas possibilidades podem não ser auto-excludentes, sobrepondo-se de modo aporético ou dialético.

Quais dados potencialmente autobiográficos são ficcionalizados em Berkeley em Bellagio e em Lorde? Essencialmente, os convites de instituições estrangeiras que João Gilberto Noll recebera para trabalhar no exterior, seja como docente, seja como escritor. De fato, esses convites desempenham, pelo menos, duas funções na estruturação dos 
dois romances: a) são o principal mote a partir do qual se desenvolvem os enredos, bem como b) fundamentam o leitmotiv característico às duas obras (os percalços afins à sobrevivência material do escritor brasileiro). Logo, tanto em Berkeley em Bellagio quanto em Lorde, apropriar-se de traços autobiográficos equivale a ficcionalizar as próprias condições de produção dos romances. Com efeito, a dependência material do escritor brasileiro é tanto aquilo que incita à recorrência à autobiografia quanto essa própria recorrência. Aliás, se é por meio da exploração de suas próprias circunstâncias de produção que, nesses romances, a ficção se estabelece como tal, a autobiografia serve de fomento ao ficcional na mesma medida em que, ao cabo, ela própria não deixa de ser ficcional. A autobiografia, portanto, é superada e, ao mesmo tempo, (ou porque) conservada pela ficção.

Ao longo de todo o enredo, tanto de Berkeley em Bellagio quanto de Lorde, a autobiografia é superada conforme a ficcionalização explicita, amplia ou, mesmo, distorce as dificuldades de sobrevivência material do escritor (por vezes, para além dos limites daquilo que se considera plausível). Esse processo visa à polarização das forças em jogo, encerrando-as em extremos antagônicos e não-comunicantes entre si. Pois o escritor brasileiro tenta, várias e várias vezes, aproximar-se seja das instituições estrangeiras em si, seja daquilo que, para ele, elas representam. Mas, aí, a desproporção entre as forças em jogo é tamanha a ponto de implicar, sempre, em sua radical despersonalização. As alternâncias entre a primeira e a terceira pessoas do discurso (em Berkeley em Bellagio), entre afasia e fluência em inglês e em português (tanto em Berkeley em Bellagio quanto em Lorde) e a passagem do comportamento modelar à marginalidade e à metamorfose final (em Lorde) - tudo concorre à absoluta incompatibilidade entre o escritor brasileiro e eles. Não há qualquer interação possível senão a passagem de um extremo a outro, sem qualquer continuidade ou, mesmo, sem plausibilidade. Ao cabo, a superação da autobiografia delineia um sujeito fracionado, fissurado, lacunar, frente a uma alteridade algo estereotípica (vide o pueril eles, frequentemente usado para denominá-la), concernente, em maior ou menor grau, a blocos econômicos globalmente hegemônicos.

Entretanto, simultaneamente a essa polarização, os dois romances projetam, em seus respectivos desfechos, possíveis identificações também. Vejamos, pois, se isso acarreta alguma modificação na polarização supracitada ou não.

Em Berkeley em Bellagio, o escritor brasileiro retorna a Porto Alegre e retoma a relação com Léo, um ex-amante, passando a viver com este e com Sarita (filha que Léo tivera em meio aos cerca de seis anos da estada do narrador no exterior). Ao final do romance, o narrador leva Sarita para conhecer a refugiada afegã pela qual se afeiçoara quando de seu retorno ao Brasil. Ao vê-la, "Sarita disse oh, assim mesmo, oh, como se ainda não soubesse falar, virgem de semântica. É que ela descobria naturalmente como ensinar uma língua para um ser estrangeiro - isso não se aprende, é puro dom, assim oh, $\mathrm{OH}$ !, como se estalasse o primeiro sentido da espécie, o espanto!, espanto diante do outro..." (NOLL, 2003, p. 105).

De um lado, uma configuração familiar não-ortodoxa (dois homens e uma filha); de outro, refugiados médio-orientais deslocados ao Brasil - tanto um quanto outro correspondem a estratos sociais marginalizados (homossexuais, exilados), que, agora, interagem em prol da efetivação e do compartilhamento de vivências sócio-históricas 
alternativas. O fato de Sarita e de a menina afegã comunicarem-se por meio de um verbo como que adâmico, "virgem de semântica", encena a superação de eventuais diferenças linguístico-culturais existentes entre ambas; diferenças tais como as enfrentadas pelo escritor brasileiro no exterior, que desencadearam sua inadequação e seu fracionamento.

Basicamente, o que diferencia a experiência do escritor brasileiro no exterior da possível amizade entre Sarita e a refugiada afegã é que, neste caso, a relação dar-se-á entre duas crianças oriundas de estratos sociais não-ortodoxos, ou seja, entre sujeitos equivalentes sob determinados aspectos, sem que haja, entre eles, uma prévia hierarquia. Já o enorme desnível econômico entre o escritor brasileiro e as instituições estrangeiras implica, de antemão, uma hierarquização solidamente enraizada, sem perspectiva alguma de mudança. Logo, uma tal promoção de intercâmbio cultural não deixa de ser algo eminentemente ideológico.

Daí que, se escritores oriundos de países subdesenvolvidos economicamente são fomentados por instituições estrangeiras (tais como a UCLA e a Fundação Rockefeller) visando, em tese, a trocas culturais, à convergência entre (ou à constituição de novos) saberes, a lógica interna de Berkeley em Bellagio explicita as falácias subjacentes a esse processo. Ao mesmo tempo, a promessa de troca e de integração culturais, representada pelo encontro entre Sarita e a menina afegã, acontece à margem do fluxo econômico globalizado, não prevendo qualquer intercâmbio senão entre aqueles já excluídos. Ou seja, não se acena, em princípio, a qualquer alteração infra-estrutural.

Isto não deixa de ser uma confirmação do dito pelo engenheiro equatoriano ao escritor brasileiro: "A realidade é um jogo. Há uma ética?, perguntei. Ética, sim, mas dentro de uma vastidão amoral. [...] Todos devem jogar seu jogo até o fim, essa a razão de estarmos aqui. O aperfeiçoamento das regras desse jogo? - ah, a única promessa" (NOLL, 2003, p. 41). O cadinho multicultural vivenciado pelo escritor brasileiro no exterior, tanto em Berkeley quanto em Bellagio, corresponde, precisamente, ao "aperfeiçoamento das regras desse jogo". Aperfeiçoamento porque, lembrando a fala do dramaturgo e professor de Chicago ao escritor brasileiro: “[...] tá certo, fora da ação eles não ficam muito tempo, querem sempre o movimento em progressão, mais e mais, e mais ainda, não importa para quê, se para matar, dominar, construir, morrer, salvar, amar, mas que se siga adiante; [...] o que acontece, o que acontece, contem, contem, o resto é ninharia para enrolar a fome intelectual dos povos subalternos" (NOLL, 2003, p. 59). Uma especulação sobre as causas, os efeitos e os sentidos aí implicados (a "fome intelectual") concerne aos “povos subalternos" porque estes não participam da "ação", isto é, do "jogo". Àqueles que o protagonizam, não cabe qualquer questionamento: sua trajetória consiste na frenética reiteração do mesmo, fundindo, àquilo que "acontece", o próprio substrato ideológico desse "acontecimento". Isto, a ponto de excluir qualquer sentido que, de tão internalizado, de tão naturalizado, não seja refratário ou, mesmo, ininteligível ao próprio entendimento.

E, tanto em Berkeley quanto em Bellagio, é o multiculturalismo esse "acontecimento". Ele corresponde ao "aperfeiçoamento das regras" porque, ao fazer com que quaisquer singularidades sucumbam à lógica do "jogo", não faz mais do que arruiná-las, submetendo-as ao já dado. Trata-se de uma espécie de vala comum, que só comporta o outro à medida que o impede de constituir-se como tal, prescrevendo, inclusive, a reincidência de sua irrealização: "Somente em face do que é absoluta e indissoluvelmente 
individuado é possível esperar que exatamente isso já tenha se dado e venha a se repetir; não é senão consentindo com isso que se satisfaz o conceito do conceito. Mas esse conceito está preso à promessa de felicidade, enquanto o mundo que recusa essa promessa é o mundo da universalidade dominante" (ADORNO, 2009, p. 309-310). ${ }^{9}$ Da mesma maneira, como "Aquilo que é semi-entendido e semi-experimentado não corresponde ao primeiro estágio da cultura, mas, sim, a seu inimigo mortal" (ADORNO, 1993, p. 104, tradução minha), ${ }^{10}$ o multiculturalismo que se vivencia tanto em Berkeley quanto em Bellagio não consiste no efetivo intercâmbio entre distintas culturas. Consiste, sim, em sua homogeneização, na neutralização de seu potencial eventualmente transgressor em relação ao contexto mesmo que o incita, em suma, à sua mera instrumentalização. O que se tem, ao cabo, é um semiculturalismo ou psendo-culturalismo, isto é, não o "primeiro estágio" de uma cultura dita plural, mas, sim, sua necrotização.

A possível relação entre Sarita e a refugiada afegã, dada a marginalidade tanto das personagens quanto do local em que interagem (Brasil), consiste em uma alternativa a esse "jogo" na medida mesma em que é mais uma possível faceta do "aperfeiçoamento de suas regras". Alternativa porque é projetado um efetivo intercâmbio sócio-cultural entre iguais. Aperfeiçoamento porque a própria igualdade aí esboçada pode ser lida como a funcionalização de uma alteridade não-ornamental, de um não-idêntico, por meio de sua redução à condição de "diferença cultural", o que escamoteia incompatibilidades, bem como não prevê qualquer alteração infra-estrutural. Aliás, seria este intercâmbio efetivo, justamente, porque realizado à margem de qualquer alteração infra-estrutural? Existiria, nele, algo que o tornaria resistente à sua instrumentalização junto à lógica do “jogo”? Ou, pelo contrário, este intercâmbio seria uma etapa preliminar (ou, pelo menos, não necessariamente resistente) à sua instrumentalização, uma vez que sua lógica e a do “jogo", de fato, pouco diferem? Delicado arriscar uma resposta a essas questões, uma vez que a narrativa não fornece subsídios para tanto. De qualquer modo, indicia-se, aí, uma provável fragilidade da aliança sócio-cultural predita por Sarita e pela refugiada afegã. $^{11}$

Se a ficcionalização dá-se a partir das dificuldades de sobrevivência material do escritor tendo em vista a polarização das forças em jogo, o processo de identificação, promovido pelo desfecho de Berkeley em Bellagio, trata de tornar essa polarização muito mais complexa. Isto, por converter o antagonismo em interdependência, bem como por evidenciar que a desigualdade material dita o tom de quaisquer conjunções sócio-culturais, seja no exterior, seja no Brasil.

De fato, a utilização dessa desigualdade material como alicerce a uma explícita e, mesmo, perversa relação de dependência é o que fundamenta Lorde desde suas primeiras sentenças. $\mathrm{O}$ fomento internacional, que poderia ser tomado, por exemplo, como índice de reconhecimento do trabalho do escritor, revela-se, ao cabo, uma forma de rebaixamento, de submissão e, mesmo, de humilhação. As alternativas sondadas em Berkeley em Bellagio são, de antemão, descartadas, não havendo espaço à narração daquilo que não seja afim à degradação do escritor brasileiro. Degradação, esta, que, partindo da submissão e da subserviência, chega à mendicância, à delinquência, ascendendo, por fim, ao completo extermínio de si mediante sua dissolução no outro. Ao cabo, a degradação do escritor brasileiro trata de extirpá-lo frente ao ambiente em que se encontra, dissolvendo-o junto 
às classes economicamente subalternas (operariado), reduzindo-o ao mesmo, ao hierarquicamente já previsto e subordinado.

Subentende-se, nisso, um certo caráter ilícito da literatura oriunda de países subdesenvolvidos economicamente quando transposta a conglomerados economicamente hegemônicos. Tanto que a possibilidade de permanência legal na Inglaterra dá-se nos seguintes termos: "estavam precisando com urgência de um professor de língua portuguesa - não de literatura, ela [a professora da Universidade da Cidade de Liverpool] sublinhou" (NOLL, 2004, p. 102, colchetes meus). Reiterando: “de língua portuguesa - não de literatura". Aí, a redução da literatura à língua, a instrumentalização que essa redução implica - eis o preço que se paga pela legalidade, bem como pela sobrevivência material. Preço, aliás, mal computado, uma vez que o desfecho do romance trata de verter essa permanência para além daquilo que se considera plausível, metamorfoseando o anônimo escritor brasileiro, em George, um estivador inglês. Ou seja, o trabalho braçal de um inglês e o intelectual de um sujeito oriundo de um país subdesenvolvido economicamente são equiparados: a permanência legal do escritor brasileiro na Inglaterra significa sua absoluta reificação, reduzindo um sujeito culturalmente emancipado (ou, pelo menos, ativo) à força bruta.

Ao desequilibrar a tensão entre autobiografia e ficção em favor desta última, Lorde radicaliza as ambivalências ideológicas da polarização traçada em Berkeley em Bellagio. Sobretudo, à medida que as hesitações entre identificar-se ao outro (ao pólo economicamente forte) e diferenciar-se dele resolvem-se sob signo do imponderável, isto é, de uma identificação tão extrema ao outro a ponto de reduzir tudo ao mesmo, exterminando o sujeito vinculado ao pólo economicamente fraco via metamorfose. Lembrando a mímesis vital (frise-se: mímesis vital, e não mímesis ficcional) conforme Adorno e Horkheimer, naquilo que ela tem de sobrevivência às custas da completa anulação de si frente à ameaça representada por um outro mais forte, fundindo-se a ou confundindo-se com este ${ }^{12}$ - ora, é algo afim àquilo que a metamorfose do escritor brasileiro representa em Lorde.

Em Berkeley em Bellagio, essa sobrevivência a partir da identificação irrestrita com o outro é um processo ainda passível de reversão ou, pelo menos, de adiamento, sendo um mínimo distanciamento ainda viável mediante o deslocamento do escritor brasileiro a um espaço não-hegemônico (caso do Brasil). Já em Lorde, de maneira flagrante, sem qualquer constrangimento, "a vida paga o tributo de sua sobrevivência assimilando-se ao que é morto” (ADORNO; HORKHEIMER, 1985, p. 168). De modo que, ao cabo, Berkeley em Bellagio e, sobretudo, Lorde dêem visibilidade ao caráter irracional, regressivo e castrador do corrente capitalismo monopolista globalizado, multinacional e multicultural.

\section{Considerações finais}

Em linhas gerais, o processo de ficcionalização em Berkeley em Bellagio e em Lorde consiste na problematização das condições de produção dos romances, instaurando um distanciamento entre aquilo que se faz e em quais circunstâncias (ou onde) é feito. De modo que, tanto quanto (ou mais do que) resultado de suas condições de produção, os romances arriscam uma reflexão sobre essas mesmas condições. A autobiografia, aí, 
serve de fomento menos à identificação pacífica entre o relatado e o vivido (de fato, ela muito mal se presta a isso) e mais como possibilidade de inscrição de um gesto crítico-reflexivo no bojo da própria narração. É nisto, pois, que consiste sua conservação em meio ao processo de ficcionalização que a supera.

Esse gesto crítico-reflexivo é traçado mediante a simulação de uma aproximação ou junção entre vivência e criação literária. E simulação em, pelo menos, dois níveis interdependentes. Primeiramente, porque a autobiografia em questão é ficcional, são personagens de ficção que narram suas experiências, e não o próprio João Gilberto Noll. E simulação, também, porque, tanto em Berkeley em Bellagio quanto em Lorde, narra-se aquilo que interdita a própria narração. E esse paradoxo é apenas aparente: afinal, não se trata de uma autobiografia stricto sensu, mas, sim, de uma autobiografia ficcional.

Fundamentalmente, essa narração daquilo que interdita a própria narração diz respeito à precariedade material do escritor, como já o vimos fartamente. Seu principal efeito é a projeção de uma precariedade, também, simbólica. Pois, inicialmente, os traços autobiográficos suscitam uma redução da autonomia da mímesis ficcional. Aí, um maior apego ao supostamente vivido é diretamente proporcional à diminuição das possibilidades de sobrevivência material do escritor (isto é, em certa medida, à diminuição de sua autonomia). Ou seja, a precariedade material desdobra-se em precariedade do ficcional, na redução deste via (ou à) autobiografia.

Essa coerção, entretanto, é adiada pelo caráter ficcional da autobiografia em questão. Pois ficcionalizar as próprias condições de produção dos romances implica tomá-las não como algo já dado, não como determinantes inexoráveis da mímesis, mas, sim, como algo em relação ao qual é possível diferenciar-se. Daí que a dependência material é transcendida simbolicamente, instaurando um distanciamento em relação ao supostamente vivido, bem como um certo impulso questionador. Impulso, este, que convoca " $[. .$.$] a$ aporia da estética no seu conjunto. O seu objeto define-se como indeterminável, negativamente. Por isso, a arte necessita da filosofia, que a interprete, para dizer o que ela não consegue dizer, enquanto que, porém, só pela arte pode ser dito, ao não dizê-lo" (ADORNO, 1988, p. 89).

Em Berkeley em Bellagio e em Lorde, uma eventual indistinção entre arte e vida dar-se-ia ao custo da redução de ambas à ideologia, de sua instrumentalização funcional junto a blocos economicamente hegemônicos. Já a dissociação entre arte e vida é o que libera a arte "da mentira de ser verdade" (ADORNO, 2008, p. 219). E é mediante essa liberação, isto é, mediante a reversão da precariedade material e simbólica por meio do exercício do ficcional; exercício, este, pautado pela intensificação das dificuldades de sobrevivência material do escritor brasileiro a ponto de fissurá-lo e, mesmo, de exterminá-lo - é aí que "A força da negatividade na obra de arte mede o abismo entre a práxis e a felicidade” (ADORNO, 1988, p. 24). E essa distância entre práxis e felicidade não deixa de ser a medida mesma do potencial crítico-reflexivo desses romances. Afinal, neles, a impossibilidade de um suprimento categórico das demandas tanto simbólicas quanto materiais, bem como de uma reconciliação entre arte e sociedade, instauram a felicidade como promessa, como projeto, como algo não já dado, mas, sim, a ser buscado. Busca, esta, cujas eventuais hesitações não deixam de ser uma precondição a seu acontecimento (afinal, só se busca aquilo que não se tem) ou, no mínimo, uma reafirmação de sua necessidade. 
${ }^{1}$ A té o momento, as publicações de João Gilberto Noll são as seguintes: O Cego e a Dançarina (contos), de 1980; A Fúria do Corpo (romance), de 1981; Bandoleiros (romance), de 1985; Rastros do Verão (romance), de 1986; Hotel Atlântico (romance), de 1989; O Quieto Animal da Esquina (romance), de 1991; Harmada (romance), de 1993; A Cén Aberto (romance), de 1996; Canoas e Marolas (romance), de 1999; Berkley em Bellagio (romance), de 2002; Mínimos, Múltiplos, Comuns(fragmentos ficcionais), de 2003; Lorde (romance), de 2004; A Máquina de Ser (contos), de 2006; Acenos e Afagos (romance), de 2008.

${ }^{2}$ A instituição norte-americana que pleiteia a estada de Noll em Bellagio é a Fundação Rockefeller. A propósito, além de professor de Literatura e Cultura Brasileira da Universidade da Califórnia (campus de Berkeley) em 1997, Noll fora escritor visitante dessa mesma instituição em 1996.

${ }^{3}$ Esclarecendo os fundamentos daquilo que, neste artigo, compreende-se por mímesis, bem como sua relação com a vida social: "A forma de classificação, com o privilégio do simbólico sobre o fluxo dos eventos e a configuração de valores que orientam a conduta social, constitui o fundo de semelhança (homoisis) sobre o qual operam as diferenças da mimesis. A obra de arte circula porque a 'outra natureza' que a enforma encontra um parâmetro nem natural, nem consciente: a forma de classificação que a sociedade em que se elabora ou em que é recebida. A mimesis não tem pois um modelo, mas traz em si um outro que a alimenta, com que dialoga, que aparece como resto que se mantém sob o arabesco da diferença, que o motiva, se não o orienta" (COSTA LIMA, 2000 , p. 57, aspas e grifos do autor). Daí que, "Por essa razão, temos definido a mímesis como produção da diferença, a partir de um horizonte de semelhança" (COSTA LIMA, 2007, p. 508, grifo do autor).

${ }^{4}$ Utiliza-se, neste artigo, a primeira reimpressão do romance, publicada pela editora Francis em 2003.

${ }^{5}$ No original em inglês: “Autobiography, then, is not a genre or a mode, but a figure of reading or of understanding". Para maiores dados sobre o caráter, por assim dizer, impuro do discurso autobiográfico, cf. Costa Lima (2007).

${ }^{6}$ Um exemplo diz respeito à ausência de espelho no apartamento que a instituição inglesa aluga para o escritor brasileiro. Ele, como que para se certificar de quem é, como que para melhor projetar sua auto-imagem no ambiente que, dali por diante, pretende torná-lo seu, compra um e observa-se: "Eu era um senhor velho. Antes não havia dúvida de que eu tinha já alguma idade. Mas agora já não me reconhecia, de tantos anos passados. O que eles queriam com um homem que já podia tão pouco?” (NOLL, 2004, p. 25). Ante a avaliação negativa de sua aparência, e dado o desejo de permanecer em Londres, o escritor toma a seguinte iniciativa: "Sim, eu dependia deles, e alguma voz interna me dizia que não me afastasse dessa dependência. Deixara a minha conta bancária no Brasil em plena estiagem. De fato, precisava entrar naquela loja de cosméticos em Piccadilly Circus e comprar o que me transformaria não digo num moço, mas num senhor de aparência exemplar. Ou quase tudo isso" (NOLL, 2004, p. 26). Logo após sair da loja de cosméticos, em passagem pela National Gallery, "eu me maquiava no banheiro da National Gallery, sem que ninguém entrasse ou saísse, como se estivesse no meu camarim para logo mais fazer a festa. Seria um homem distinto, a pele macia de um gentleman. Todos iriam me ouvir, o auditório lotado. O que me restava a dizer depois de ter dito tanto durante aqueles anos todos? Ter dito mesmo o quê? Sei que eu me maquiava à perfeição" (NOLL, 2004, p. 27).

${ }^{7}$ Vale lembrar que eventos semelhantes ao desfecho de Lorde não são estranhos às narrativas de Noll. É o caso, por exemplo, de "Miguel, Miguel, Não Tens Abelha e Vendes Mel", conto de O Cego e a Dançarina, dos romances A Fúria do Corpo, A Cén Aberto etc. A partir disso, pode-se pressupor que Lorde delineia uma espécie de síntese entre a experiência representada por Berkeley em Bellagio (as dificuldades de sobrevivência material do escritor e sua relação com o mecenato internacional) e a obra pregressa de Noll. Lorde, inclusive, não deixa de representar o encerramento de um ciclo, incitando o autor a uma espécie de reinício - basta ver que, em seguida, Noll retorna ao conto (A Máquina de Ser), gênero em que não mais se aventurara desde 1980 (desde O Cego e a Dançarina).

${ }^{8}$ Ainda assim, tanto à interpretação de Berkeley em Bellagio quanto à de Lorde, parece pouco apropriado o conceito de autoficção, articulado por Serge Doubrovsky (1991). Situando-se na tensão mesma entre autobiografia e ficção, a autoficção caracteriza-se pela identificação entre narrador (e/ou personagem) e autor empírico, mas não pela identificação entre o narrado e o supostamente vivido. Ou seja, trata-se de ficcionalizar a si mesmo para além dos limites da experiência empírico-perceptual. Como visto, nos romances de Noll, a ficcionalização desencadeia o radical fracionamento do sujeito (Berkeley em Bellagio), quando não sua dissolução (Lorde). Isto inviabiliza a identificação, basilar à autoficção, entre narrador (e/ou personagem) e autor empírico. 
"Adorno, aí, alude à seguinte formulação de Stendhal: "A beleza não é mais do que a promessa de felicidade" (1857, p. 34, grifo do autor. No original em francês: “La beauté n'est que la promesse du bonheur"). Esta alusão também se repete em diversas passagens de sua Teoria Estética (cf. ADORNO, 1988).

${ }^{10} \mathrm{Na}$ versão em inglês aqui utilizada: "What is half-understood and half-experienced is not the first stage of culture but its mortal enemy" (cf. tb., ADORNO, 2004).

${ }^{11}$ Fora do âmbito da ficção, há, ainda, outro saldo negativo a esse processo: em razão da inadaptabilidade cultural e, sobretudo, da penúria material, três das cinco famílias afegãs que se refugiaram em Porto Alegre ao final de 2001 retornaram a seu país de origem em meados de 2003 (cf. Afeganistão: frustradas, três famílias de refugiados deixam o Brasil, Folha de São Paulo, 21 mai. 2003).

${ }^{12}$ As considerações de Adorno e de Horkheimer sobre a mímesis vital podem ser encontradas na Dialética do Esclarecimento (1985); mais precisamente, nos primeiro e segundo capítulos ("O Conceito de Esclarecimento" e "Excurso I: Ulisses ou Mito e Esclarecimento") e, principalmente, em "Elementos do Anti-Semitismo: Limites do Esclarecimento". Não se trata de uma reflexão sistematizada em torno da mímesis vital, mas, antes, de apontamentos em meio a ensaios focados em outros assuntos. Entretanto, pode-se recorrer à síntese bastante precisa de Jeanne Marie Gagnebin: “[...] a mimesis integra os procedimentos mágicos que têm por alvo a defesa do sujeito fraco e amedrontado contra os poderosos inimigos exteriores. Na tentativa de escapar ao perigo, o homem 'primitivo' se assimila, torna-se semelhante ao meio ambiente (assim como a borboleta sobre a folha) para abolir a diferença e a distância que permitem ao animal reconhecê-lo e devorá-lo; ou, então, veste a máscara semelhante ao deus aterrorizante para apaziguá-lo pela sua imagem e semelhança. Essa estratégia mágico-mimética não é somente ineficaz. Ela é cruel e regressiva porque implica o sujeito não enfrentar o perigo, mas desistir de sua posição de sujeito, de sua identidade própria, para salvar a si próprio, perdendo-se a si mesmo. Dialética fatal que prefigura, na interpretação de Adorno e de Horkheimer, os ardis da razão" (GAGNEBIN, 2006, p. 68, aspas e grifos da autora; cf., tb., DUARTE, 1993; GAGNEBIN, 2005).

\section{Bibliografia}

ADORNO, Theodor W. Teoria estética. Trad. Artur Morão. Lisboa: Ed. 70, 1988.

. Theory of pseudo-culture (1959). Trans. Deborah Cook. Telos: a quarterly journal of critical thought, New York, n. 95, p. 15-38, spring 1993.

. Introducción a una discusión sobre la "Teoria de la pseudocultura". In: Escritos sociológicos I. Org. Rolf Tiedemann; Gretel Adorno; Susan Buck-Morss; Klaus Schultz. Trad. Agustín González Ruiz. Madrid: Akal, 2004. p. 532-535. Obra Completa, v. 8.

Minima moralia: reflexões a partir da vida lesada. Trad. Gabriel Cohn. Rio de Janeiro: Beco do Azougue, 2008.

Dialética negativa. Trad. Marco Antonio Casanova. Rev. Eduardo Soares Neves Silva. Rio de Janeiro: Jorge Zahar, 2009.

; HORKHEIMER, Max. Dialética do esclarecimento: fragmentos filosóficos. Trad. Guido Antonio de Almeida. Rio de Janeiro: Jorge Zahar, 1985.

AFEGANISTÃO: frustradas, três famílias de refugiados deixam o Brasil. Folha de São Paulo, São Paulo, 21 mai. 2003. Folha Mundo. Disponível em: <http://www1.folha.uol.com.br/fsp/mundo/ ft2105200319.htm>. Acesso em: 16 jun. 2009.

AVELAR, Idelber. Bildungsroman em suspenso: quem ainda aprende com os relatos e viagens? In: Alegorias da derrota: a ficção pós-ditatorial e o trabalho do luto na América latina. Trad. Saulo Gouveia. Belo Horizonte: Ed. UFMG, 2003. p. 213-234.

CARNEIRO, Flávio. No país do presente: ficção brasileira no início do século XXI. Rio de Janeiro: Rocco, 2005.

COSTA LIMA, Luiz. Mimesis: desafio ao pensamento. Rio de Janeiro: Civilização Brasileira, 2000. Limites da vor: Montaigne, Schlegel, Kafka. 2. ed. rev. Rio de Janeiro: Topbooks, 2005. Sociedade e discurso ficcional. In: . Trilogia do controle. 3. ed. rev. Rio de Janeiro: Topbooks, 2007. p. 233-521.

DE MAN, Paul. Autobiography as de-facement. Modern language notes, Baltimore, v. 94, n. 5, p. 919-930, 1979. Disponível em: <http://www.jstor.org/stable/2906560>. Acesso em: 21 abr. 2009. 
DOUBROVSKY, Serge. Autobiographie/autofiction. Revue des sciences humaines, Lille, n. 224, p.17-25, Octobre/Décembre 1991.

DUARTE, Rodrigo Antonio de Paiva. Mimesis e racionalidade: a concepção de domínio da natureza em Theodor W. Adorno. São Paulo: Loyola, 1993.

GAGNEBIN, Jeanne Marie. Do conceito de mímesis no pensamento de Adorno e de Benjamin. In: Setes aulas sobre linguagem, memória e história. 2. ed. Rio de Janeiro: Imago, 2005. p. 79-104. "Após Auschwitz". In: . Lembrar escrever esquecer. São Paulo: Ed. 34, 2006. p. 59-81.

KLINGER, Diana Irene. Escritas de si, escritas do outro: o retorno do autor e a virada etnográfica. Rio de Janeiro: 7 Letras, 2007.

LEJEUNE, Philippe. O pacto autobiográfico: de Rousseau à internet. Org. Jovita Maria Gerheim Noronha. Trad. Jovita Maria Gerheim Noronha; Maria Inês Coimbra Guedes. Belo Horizonte: Ed. UFMG, 2008.

MORICONI, Ítalo. Circuitos contemporâneos do literário (indicações de pesquisa). Gragoatá, Niterói, n. 20, p. 147-163, $1^{\circ}$ sem. 2006.

NOLL, João Gilberto. Berkeley em Bellagio. São Paulo: Francis, 2003. 106 p. . Lorde. São Paulo: Francis, 2004. 111 p.

PINTO, Manuel da Costa. Literatura brasileira hoje. São Paulo: Publifolha, 2005.

STENDHAL, Henry-Marie Beyle de. De l'amour. Paris: Michel Lévy Frères, 1857. Disponível em: http:// books.google.com.br/books?id=Ei-LxVVkyOUC\&dq $=\mathrm{de}+1 \% 27$ amour + Stendhal\&source $=$ gbs_ navlinks_s>.Acesso em: 16 jun. 2009.

VIEGAS, Ana Cláudia Coutinho. O "retorno do autor": relatos de e sobre escritores contemporâneos. In: VALLADARES, Henriqueta do Coutto Prado (Org.). Paisagens ficcionais: perspectivas entre o eu e o outro. Rio de Janeiro: 7 Letras, 2007. p. 13-26. 
